\title{
研究連絡委員会の活動から
}

日本学術会議では、第17期活動計画（本誌平成9年12月号8ページ参照)に基づく審 議を各委員会が行うほか、シンポジウム等の開催を行っています。

今回は、人工物設計・生産研究連絡委員会および専門委員会の活動を、すでに開催 されたシンポジウム等の開催の状況を交えて紹介いたします。

\section{設計の質的転換と 未来への学術研究}

一人工物設計・生産研究連絡委員会/設計工学専門委員会の活動から—

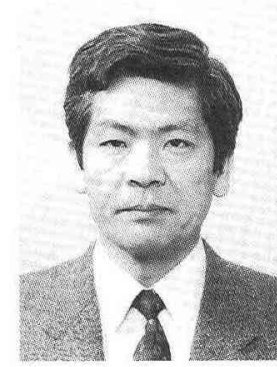

中島 尚正

\section{人工環境と設計・生産}

われわれの生活は、人工物で満たされた人工 環境のなかで営まれている。部屋のなかを見渡 しても、目につくものはほとんどが人工物である。

確かに人工環境の発展は、豊かさという人類 の夢の実現に貢献してきた。しかし、一方で、 人工環境の高度化は、地球環境問題、資源工ネ ルギーの大規模消費、廃棄物の堆積、事故の日 常化と大型化、経済格差、等々の解決困難な幾 多の問題の原因を作っている。

人工物は設計と生産の活動によって作り出さ れ、絶え間なく生産される大量の人工物が蓄積 して人工環境が形成される。したがって、設計と 生産の活動は、単に、モノつくりに関与するだけ でなく、人工環境形成の素過程として機能し、将
来の人工環境にも大きな影響を与えるものであ ると認識することが重要である。つまり、われわ れの現在と未来の生活圈に重大な影響を与えて いるのが、現在の設計と生産の営みなのである。

日本学術会議の工学を扱う第5部に、平成10年 度、第 17 期より、人工物設計・生産研究連絡委員 会が設けられた。この研連には八つの專門委員 会が属していて、その一つが設計工学専門委員 会であり、筆者がこの委員長を務めている。

\section{設計の質的転換}

設計工学専門委員会では、まず、人工物の設 計と生産に起因する上述の諸問題に注目し、問 題解決には設計と生産の新たなパラダイムの探 求が不可欠であるという認識に立って議論を重 ねた。その結果、様々な設計分野に打ける設計 
の考え方や価值意識の変化を洞察することが、 新パラダイムの探求に有効であると判断し、設 計に関係する学会に広く呼びかけて、「設計の質 的転換」と題する日本学術会議50周年記念シン ポジウムを開催することとした。

開催日は1999年5月12・13日。日本機械学会 (幹事学会)、精密工学会、人工知能学会、日本 建築学会、日本デザイン学会、日本設計工学会、 日本造船学会、日本航空宇宙学会が共催学会と して参加した。これらの共催学会から推薦を受 けた講師による20件の講演、吉川弘之学術会議 会長による特別講演、馬場靖憲東大人工物工学 研究センター教授による基調講演、および総合 討論を行った。出席者は大学・産業界を中心に 約200名であった。

以下に、設計打よびその研究に関する質的転 換の要点を紹介する。

\section{シンセシスの解明と高度な知識処理}

要求を実現する具体的な手段や方法を案出す る思考活動をシンセシスという。設計に扔ける 根本的な思考活動であるシンセシスを科学的に 理解しようとする試みは、国際的にみてもこれ までほとんど例がなかった。

だが、深い基礎に根ざして応用に発展する研 究の重要性が理解されるようになり、1996年よ り日本学術振興会の未来開拓学術研究推進事業 の中で、「シンセシスの科学」研究が推進されて いる。

設計における工学的問題に対して具体的な解 決法を提示する設計方法論は、1960年代から研 究が盛んになり、すでに、複雑な設計問題を数 学モデルに置き換えて、最適な設計解を合理的 に導く様々な方法が実用に供されている。しか
し、設計者のより深い思考活動を支援すること は未解決であった。設計者に負担をかけずにコ ンピュータにより複雑で高度な知識処理を実現 するために、エージェントやオントロジーなど の新たな概念に基づく方法が研究されている。

\section{感性、福祉、環境の重視}

質的転換として、設計のスコープの広がりを 指摘することもできる。例えば、感性が重視さ れる造形を対象にした創造性設計支援も試みら れている。福祉や地球環境の問題は設計研究に 多くの課題を提供している。例えば、高齢者や 身体障害者と健常者が、生活環境を共有するた めのバリアフリーデザイン、ユニバーサルデザ インのための方法論、人工物のライフサイクル 全体を見通して、機能のメンテナンス、構成部 品の再生利用、廃棄処理の容易化等を前提に置 いた最適設計等。

\section{長期的視野に立つた設計・生産研究}

設計・生産の活動は、人工環境の形成におけ る素過程として機能することから、現時点に留 まらず将来の生活圈にも多大な影響を及ぼす。

そのために、設計・生産の学術研究において は、文明論的な視野やその倫理的な側面や価值 をも含む長期的な観点をもつことが重要である。 設計工学専門委員会では、第17期のまとめとし て、数十年の将来を視野に入れた「未来に調和 した人工物の設計・生産」の長期的研究推進を 提案する予定であり、現在、検討を進めている。

中島 尚正（なかじま なおまさ 1941年生） 日本学術会議 人工物設計・生産研究連絡委員会設計工学 専門委員会委員長、東京大学大学院工学系研究科長・工 学部長、工学博士

専門：機械工学、人工物工学 